\title{
Bicycle helmet campaigns and head injuries among children. Does poverty matter?
}

\author{
C Farley, L Laflamme, M Vaez
}

J Epidemiol Community Health 2003;57:668-672

See end of article for

authors' affiliations

.....................

Correspondence to: Lucie Laflamme, Karolinska Institutet, Department of Public Health Sciences, Division of Social

Medicine, SE-17176

Stockholm, Sweden;

Lucie.laflamme@smd.sll.se

Accepted for publication 28 February 2003

\begin{abstract}
Objectives: To assess the impact of a community based bicycle helmet programme aimed at children aged 5-12 years (about 140000 ) from poor and well off municipalities.

Methods: A quasi-experimental design, including a control group, was used. Changes in the risk of bicycle related head injuries leading to hospitalisation were measured, using rates ratios.

Results: Reductions in bicycle related head injuries were registered in both categories of municipalities. Compared with the pre-programme period, the protective effect of the programme during the postprogramme period was as significant among children from poor municipalities $(R R=0.4595 \% \mathrm{Cl} 0.26$ to 0.78$)$ as among those from richer municipalities $(R R=0.5595 \% \mathrm{Cl} 0.41$ to 0.75$)$.

Conclusion: Population based educational programmes may have a favourable impact on injury risks in poor areas despite lower adoption of protective behaviours.
\end{abstract}

B icycling is a popular recreational activity and a principal mode of transportation for children. However, bicycle related injuries, especially head injuries, are a major public health problem in Québec, ${ }^{1}$ in Canada, ${ }^{2-5}$ and elsewhere. ${ }^{6-9}$ The use of helmets has been cited and promoted as a strategy for reducing the frequency and severity of bicycle related head injuries. ${ }^{10-12}$ Educational interventions are popular approaches that attempt to increase voluntary bicycle helmet use, and have been found to be effective in that particular sense. ${ }^{13-17}$

Few studies, however, have examined the impact of educational programmes on injury rates. ${ }^{18-20}$ In the particular case of the wearing of bicycle helmets in childhood, two studies, one conducted in Seattle, Washington, ${ }^{18}$ the other in Victoria, Australia ${ }^{19}$ point to significant reductions in bicycle related head injuries. By contrast, a study from New Zealand suggests that an increase in helmet wearing has little association with the occurrence of serious head injuries among bicyclists. ${ }^{20}$

In summary, despite their widespread use, there is a paucity of studies assessing the impact of population based, bicycle helmet wearing educational programmes on head injury occurrence. In addition, little is known about their differential impact on people from different living circumstances and environments. This study was embarked upon so as to assess the differential impact of a four year bicycle helmet promotion programme on the occurrence of bicycle related head injuries among children from areas of different socioeconomic status.

\section{BICYCLE HELMET PROMOTION PROGRAMME IN THE MONTÉRÉGIE, 1990 TO 1993}

The programme, in place during the period 1990 to 1993, had a population based approach, forming part of a five year plan that aimed at reducing road injury mortality and morbidity in the entire Montérégie region. The programme targeted elementary school children, 5 to 12 years of age, attending both French and English publicly provided schools in the Montérégie (about 380 schools and 140000 children). The objective of the programme was to increase the helmet wearing rate from $1.3 \%$ to $20 \%$.

A preliminary study identified the factors that were most likely to influence children's intentions to use a helmet, and inspired the advocacy messages adopted during the programme. ${ }^{21}$ It was designed on the basis of the PRECEDE framework developed by Green $e t a^{22}$ and on the theory of diffusion of innovations proposed by Rogers. ${ }^{23}$ Figure 1 describes the different activities undertaken during the programme and how they related to predisposing, enabling and reinforcing factors in line with the PRECEDE model.

The programme started in 1990, and its activities were repeated every year from April to August (the spring and summer bicycling season) through to 1993. Intervention strategies focused on persuasive communication and community organisation. Standard educational activities to modify attitudes, beliefs, and values with regard to helmet use were undertaken, mainly in schools during May and June. Complementarily, community based activities focusing on facilitating helmet acquisition and reinforcing helmet use were conducted from April to August by police officers, social clubs, sporting goods retailers, municipal leisure departments, and the stakeholders involved in cycling events.

Behavioural changes in the targeted populations have been measured by two studies to date. The first, based on a self administered questionnaire, showed that the programme was the main predictor of high intention to use a bicycle helmet, and that it had a significant effect on helmet ownership (1989: 4\%; 1991: 26\%; 1993: 56\%). ${ }^{13}$ The second, based on repeated observational studies, reported a significant increase in helmet use over time $(1.3 \%, 4.1 \%, 9.6 \%, 15.6 \%$, and $32.5 \%$, for the years 1988, 1990, 1991, 1992, and 1993 respectively)..$^{14}$ However, the programme proved to be only one in three times as effective in poor municipalities as in richer ones. When the programme ended, children from poor areas were underrepresented among voluntary helmet users.

This imbalance in the penetration of target behaviour according to type of municipality warranted further evaluation and follow up of the programme's effectiveness in changing subsequent injury risk levels later on (which was the object of this study).

\section{METHODS}

A quasi-experimental design ${ }^{24}$ was used, covering the preimplementation and post-implementation periods as well as 


\begin{tabular}{|c|c|c|c|}
\hline \multirow[t]{2}{*}{ Strategy } & Factors & Activities & Process/implementation data \\
\hline & Predisposing factors & Raise parental and child awareness & \multirow[b]{2}{*}{$\begin{array}{l}\text { Activities were concentrated during the spring and summer each year } \\
\text { from } 1990 \text { to } 1993 \\
\text { - On average } 216 \text { schools and } 250 \text { agencies participated in the } \\
\text { programme each year } \\
\text { - } 12214 \text { posters, } 319944 \text { pamphlets and } 4965 \text { educational } \\
\text { guides were distributed } \\
\text { Exposure to the programme } \\
\text { Among the } 1089 \text { pupils who completed the evaluation questionnaire } \\
\text { at the end of the programme: } \\
\text { - } 85 \% \text { mentioned having heard about the programme } \\
\text { - } 60 \% \text { learned of the programme in school, } 42 \% \text { of whom } \\
\text { participated in three activities } \\
\text { - } 50 \% \text { participated in community based activities, } 49 \% \text { of whom } \\
\text { participated in two activities }\end{array}$} \\
\hline $\begin{array}{l}\text { Persuasive communication } \\
\text { - Much repetition in several } \\
\text { sources } \\
\text { (media, school, community) } \\
\text { - High quality production of } \\
\text { materials }\end{array}$ & $\begin{array}{l}\text { - Attitudes } \\
\text { - Beliefs } \\
\text { - Values } \\
\text { - Knowledge }\end{array}$ & $\begin{array}{l}\text { Elementary school and } \\
\text { community setting } \\
\text { - Promotional posters } \\
\text { - Pamphlets for parents } \\
\text { - Educational guides for teachers } \\
\text { and municipal recreation } \\
\text { departments } \\
\text { - Themes for discussion, and } \\
\text { competitions } \\
\text { - Exposure to mass media }\end{array}$ & \\
\hline & Enabling factors & \multicolumn{2}{|c|}{$\begin{array}{l}\text { Decrease the cost of helmets } \\
\text { Increase availability of helmets for school age children }\end{array}$} \\
\hline $\begin{array}{l}\text { Bicycle helmet committee } \\
\text { - to mobilise local involvement } \\
\text { in activities } \\
\text { Representative from: } \\
\text { - School boards } \\
\text { - Optimist clubs } \\
\text { - Police association } \\
\text { - Municipal recreation }\end{array}$ & $\begin{array}{l}\text { - Skills } \\
\text { - Price } \\
\text { - Availability }\end{array}$ & $\begin{array}{l}\text { School and community setting } \\
\text { - Discount coupons } 5 \$, 10 \$ \\
\text { - Bulk buying with trade fairs for } \\
\text { parents } \\
\text { - Distribution of free helmets } \\
\text { Retailers ( } 110 \text { stores) } \\
\text { - Small size approved helmets } \\
\text { - Instructions for wearing }\end{array}$ & $\begin{array}{l}\text { From } 1990 \text { to } 1993 \\
\text { - } 72672 \text { discount coupons were distributed } \\
\text { - } 249 \text { bulk buys took place } \\
\text { From } 1990 \text { to } 1993 \\
\text { - } 226 \text { small size helmet stands took place } \\
\text { - } 37538 \text { hang tags (message: hang helmet up on handlebars) } \\
\text { - } 1336 \text { activities arranged by retailers (pamphlets and posters } \\
\text { distribution, discount coupons authorised, helmets on sale, etc) }\end{array}$ \\
\hline $\begin{array}{l}\text { departments } \\
\text { - Sporting associations } \\
\text { - Public health department }\end{array}$ & $\begin{array}{l}\text { Reinforcing factors } \\
\text { - Social support } \\
\text { - Peer influence } \\
\text { - Significant } \\
\text { persons }\end{array}$ & \multicolumn{2}{|c|}{ 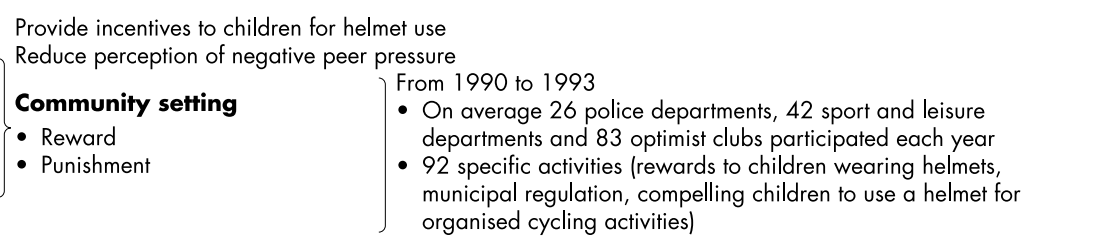 } \\
\hline
\end{tabular}

Figure 1 Summary of the bicycle helmet programme based on the PRECEDE model and of its evaluation.

the programme period itself. The population targeted by the programme-that of the Montérégie-included 138820 children 5 to 12 years of age (census of 1996). ${ }^{25}$ The community chosen for comparison was used for the earlier programme evaluations, ${ }^{1314}$ and amounted to 83529 children of the same age (census of 1996). ${ }^{25}$ It was chosen on the grounds that it did not have a programme promoting bicycle helmet wearing, but had similar population characteristics. The comparison community is situated about 40 kilometres north of Montreal.

Both the target and comparison communities were divided into two categories of municipality (210 and 98 respectively), poor or average rich, according to Haan's area based measure of socioeconomic position. ${ }^{26}$ Municipalities with a proportion of households below the low income threshold equal to or greater than $20 \%$, as defined by Statistic Canada, ${ }^{27}$ and according to the census of 1996, were categorised as poor (range: target from $20.1 \%$ to $38.9 \%$, comparison from $20.1 \%$ to $40.4 \%$ ) and those with a proportion less than 20\% were categorised average rich (range: target from $0 \%$ to $19.7 \%$, comparison from $0 \%$ to $19.3 \%$ ). The number of municipalities categorised as poor was slightly lower than in the target community (24 compared with 27), but these municipalities comprised more than twice as many children from the target age group (27 450 and 10400 children, respectively). The number of municipalities categorised as average rich was more than twice as high in the target community (186 compared with $71)$, and comprised nearly twice as many children from the target age group (111370 compared with 73 129).

As the number of fatalities was low (about two per year during the study period 1988-1996), the evaluation focused on serious bicycle injuries - that is, injuries that resulted in hospitalisation for at least one night, excluding death. Hospitalisation data were obtained from MedEcho for the years 1988 to 1996. MedEcho is a standardised provincial government inpatient register that offers full coverage of hospitals in the province. The definition of "head injury" used in this study followed that of Thompson et al, ${ }^{10}$ - that is, any area of the head that a helmet might be expected to protect. Accordingly, following the WHO International Classification of Diseases- $9{ }^{28}$ all hospitalisations for trauma codes (800-999), and particularly for head and facial trauma codes 800-804, 850-854, 872, 873.0, 873.1, 873.8 , and 873.9 relating to bicycle collision codes 813.6, 821.6, and 826.1, were extracted from MedEcho for the Montérégie residents and for the comparison community. For each injury, data on the age, sex, and municipality of residence of the victims were also available.

During the study period, a total of 1300 children aged 5 to 12 years were hospitalised after a bicycle collision. Of these, $65 \%$ (842 cases) came from the target community, and 35\% (458 cases) from the comparison community. In $41 \%$ (537) of cases, the main cause of hospitalisation was a head injury; in $22 \%$, the child lived in a poor municipality.

For the analyses, three periods of three years, covering the pre-programme, programme, and post-programme periods, and two types of comparisons were used. The first type of comparison was performed within period and category of municipality of similar socioeconomic status but between children from the target and comparison communities. Differences in the risk of bicycle related head injuries, expressed as incidence rates of hospitalisation per 1000 children, were measured using rates ratios (RR) with 95\% confidence intervals (CI). In addition, changes in injury risks within category of municipality and between periods were considered, using the pre-implementation period as reference.

In the compilations, the total number of exposed children during each period, and for each category of municipality, was assumed to be that of the 1994-1996 post-programme period for which census data were available. We know from other sources that, globally, the number of children aged 5-12 years decreased by $2 \%$ in the target community and increased by $7.5 \%$ in the comparison community. We do not know, however, whether these changes applied to the same extent —and in the same direction-among children from both categories of municipality. 
Table 1 Rates ratios (RR) with 95\% confidence intervals (Cl) by part of body injured and period of observation for children aged 5-12 years from poor and average rich municipalities

\begin{tabular}{|c|c|c|c|c|}
\hline & \multicolumn{2}{|c|}{ Poor municipalities } & \multicolumn{2}{|c|}{ Average rich municipalities } \\
\hline & $\begin{array}{l}\text { Incidence rate } \\
\text { Per } 1000\end{array}$ & $\begin{array}{l}\text { Rates ratios }(95 \% \\
\mathrm{Cl})\end{array}$ & $\begin{array}{l}\text { Incidence rate } \\
\text { Per } 1000\end{array}$ & $\begin{array}{l}\text { Rates ratios }(95 \% \\
\mathrm{Cl})\end{array}$ \\
\hline \multicolumn{5}{|c|}{ A: Head injuries } \\
\hline \multicolumn{5}{|c|}{ Pre-implementation 1988-1990 } \\
\hline Comparison & 0.48 & 1.00 & 0.70 & 1.00 \\
\hline Target & 1.53 & 3.19 (1.29 to 8.05$)$ & 1.04 & 1.49 (1.07 to 2.08$)$ \\
\hline Total injury & 47 & & 166 & \\
\hline \multicolumn{5}{|c|}{ Implementation 1991-1993 } \\
\hline Comparison & 1.06 & 1.00 & 0.70 & 1.00 \\
\hline Target & 1.06 & 0.99 (0.49 to 2.00$)$ & 0.83 & 1.18 (0.84 to 1.67$)$ \\
\hline Total injury & 40 & & 143 & \\
\hline \multicolumn{5}{|c|}{ Post-implementation 1994-1996 } \\
\hline Comparison & 0.64 & 1.00 & 0.68 & 1.00 \\
\hline Target & 0.69 & $1.03(0.43$ to 2.45$)$ & 0.58 & 0.84 (0.58 to 1.22$)$ \\
\hline Total njury & 26 & & 114 & \\
\hline \multicolumn{5}{|c|}{ B: Other injuries } \\
\hline \multicolumn{5}{|c|}{ Pre-implementation 1988-1990 } \\
\hline Comparison & 1.63 & 1.00 & 1.14 & 1.00 \\
\hline Target & 1.49 & $0.91(0.52$ to 1.61$)$ & 1.02 & 0.90 (0.68 to 1.20$)$ \\
\hline Total injury & 58 & & 197 & \\
\hline \multicolumn{5}{|c|}{ Implementation 1991-1993 } \\
\hline Comparison & 1.73 & 1.00 & 1.05 & 1.00 \\
\hline Target & 1.68 & $0.97(0.56$ to 1.67$)$ & 1.10 & 1.04 (0.78 to 1.38$)$ \\
\hline Total injury & 64 & & 199 & \\
\hline \multicolumn{5}{|c|}{ Post-implementation 1994-1996 } \\
\hline Comparison & 1.35 & 1.00 & 1.01 & 1.00 \\
\hline Target & 1.41 & 1.06 (0.57 to 1.94$)$ & 1.06 & $1.05(0.78$ to 1.40$)$ \\
\hline Total injury & 53 & & 192 & \\
\hline
\end{tabular}

Similar analyses to the two mentioned above were performed with regard to bicycle related injuries other than those to the head. These were designed to ascertain whether changes in risk exposure might have occurred, and conducted in light of the debate concerning the possibility of a reduction in bicycle use attributable to the implementation of a bicycle helmet wearing campaign (mainly in the context of law enforcement). ${ }^{29}$

SPSS software was used for the analyses.

\section{RESULTS}

Table 1 (part A) provides evidence of the programme's impact on the risk of hospitalisation for head injury after a bicycle collision, by observation period for each category of municipality. During the period that preceded implementation of the programme and for each category of municipality, children from the target community showed a significantly higher risk of hospitalisation than those from the comparison community for both categories of socioeconomic status (poor: $\mathrm{RR}=3.19$, $95 \% \mathrm{CI}=1.29$ to 8.05 , average rich: $\mathrm{RR}=1.49,95 \% \mathrm{CI}=1.07$ to 2.08 ). For the subsequent periods (implementation and postimplementation), the difference between the two groups decreased and was statistically non-significant.

With regard to the risk of hospitalisation for other types of injuries related to bicycle collisions, and considering each category of municipality, no significant difference was found between municipalities of comparable socioeconomic status (table 1, part B).

Table 2 highlights changes between periods with regard to risk of hospitalisation within the target and comparison communities for each category of socioeconomic status. Table 2 (part A) demonstrates that children from the municipalities exposed to the programme, both poor and average rich, showed a significant decrease in the risk of hospitalisation after a bicycle related head injury during the postimplementation period $(\mathrm{RR}=0.45,95 \% \mathrm{CI}=0.26$ to 0.78 and
$\mathrm{RR}=0.55,95 \% \mathrm{CI}=0.41$ to 0.75 respectively). No such difference between periods was observed in the comparison communities.

With regard to the risk of hospitalisation for a bicycle related injury other than one to the head (table 2, part B), no significant differences were observed between either phases or groups.

\section{DISCUSSION}

This study sheds light on a number of findings of considerable importance for the development and evaluation of educational injury prevention programmes promoting the voluntary (compared with mandatory) adoption of safe behaviours at community level. Firstly, the programme under study significantly reduced the incidence of hospitalisation for bicycle related head injuries. Secondly, relative gains were registered, after the programme ended, among children from both poor and average rich municipalities. Thirdly, the gains were comparable between categories of municipality despite a lower adoption rate of protective target behaviour in poor municipalities. ${ }^{14}$

The risk of bicycle related head injury of children from the Montérégie was higher than that of the comparison community in the pre-programme phase, but was no longer so during the post-programme phase. The initial difference may be a reflection of a variety of circumstances disfavouring children in the target community-in bicycling habits (for example, age at debut, habits, and skills), and also in their physical and social environments. Nevertheless, it seems reasonable to suppose that the attainment of comparable risk levels after the programme are attributable, at least in part, to the progressive and increasing adoption of the protective behaviour promoted by the programme. Considering the changes in the other types of bicycle related injuries, the reduced levels could scarcely be the result of diminished bicycle use in the target community 
Table 2 Impact of the bicycle helmet wearing programme on head injuries among 5 to 12 year old children, comparing the implementation and post-implementation periods with the pre-implementation period, and considering different categories of municipalities within the experimental and comparison groups

\begin{tabular}{|c|c|c|c|c|c|c|c|c|}
\hline & \multicolumn{4}{|c|}{ Target community } & \multicolumn{4}{|c|}{ Comparison community } \\
\hline & \multicolumn{2}{|c|}{ Poor municipalities } & \multicolumn{2}{|c|}{ Average rich municipalities } & \multicolumn{2}{|c|}{ Poor municipalities } & \multicolumn{2}{|c|}{ Average rich municipalities } \\
\hline & $\begin{array}{l}\text { Incidence } \\
\text { rate/1000 }\end{array}$ & $\begin{array}{l}\text { Rates ratios } \\
(95 \% \mathrm{Cl})\end{array}$ & $\begin{array}{l}\text { Incidence } \\
\text { rate/1000 }\end{array}$ & $\begin{array}{l}\text { Rates ratios } \\
(95 \% \mathrm{Cl})\end{array}$ & $\begin{array}{l}\text { Incidence } \\
\text { rate/1000 }\end{array}$ & $\begin{array}{l}\text { Rates ratios } \\
(95 \% \mathrm{Cl})\end{array}$ & $\begin{array}{l}\text { Incidence } \\
\text { rate/1000 }\end{array}$ & $\begin{array}{l}\text { Rates ratios }(95 \% \\
\mathrm{Cl})\end{array}$ \\
\hline $\begin{array}{l}\text { A: Head injuries } \\
\text { Pre-implementation } \\
1988-1990\end{array}$ & 1.53 & 1.00 & 1.04 & 1.00 & 0.48 & 1.00 & 0.70 & 1.00 \\
\hline Implementation 1991-1993 & 1.06 & $\begin{array}{l}0.69 \\
10.43 \text { to } 1.111)\end{array}$ & 0.83 & $\begin{array}{l}0.79 \\
10.60 \text { to } 1.04)\end{array}$ & 1.06 & $\begin{array}{l}2.20 \\
(0.77 \text { to } 6.34)\end{array}$ & 0.70 & $\begin{array}{l}1.00 \\
10.68 \text { to } 1.471\end{array}$ \\
\hline $\begin{array}{l}\text { Post-implementation } \\
\text { 1994-1996 }\end{array}$ & 0.69 & $\begin{array}{l}0.45 \\
(0.26 \text { to } 0.78)\end{array}$ & 0.58 & $\begin{array}{l}0.55 \\
(0.41 \text { to } 0.75)\end{array}$ & 0.64 & $\begin{array}{l}1.40 \\
(0.44 \text { to } 4.41)\end{array}$ & 0.68 & $\begin{array}{l}0.98 \\
(0.65 \text { to } 1.45)\end{array}$ \\
\hline \multicolumn{9}{|l|}{ B: Others injuries } \\
\hline $\begin{array}{l}\text { Pre-implementation } \\
1988-1990\end{array}$ & 1.49 & 1.00 & 1.02 & 1.00 & 1.63 & 1.00 & 1.14 & 1.00 \\
\hline Implementation 1991-1993 & 1.68 & $\begin{array}{l}1.12 \\
(0.74 \text { to } 1.71)\end{array}$ & 1.10 & $\begin{array}{l}1.07 \\
(0.83 \text { to } 1.38)\end{array}$ & 1.73 & $\begin{array}{l}1.06 \\
(0.54 \text { to } 2.06)\end{array}$ & 1.05 & $\begin{array}{l}0.93 \\
(0.68 \text { to } 1.27)\end{array}$ \\
\hline $\begin{array}{l}\text { Post-implementation } \\
\text { 1994-1996 }\end{array}$ & 1.42 & $\begin{array}{l}0.95 \\
(0.61 \text { to } 1.47)\end{array}$ & 1.06 & $\begin{array}{l}1.04 \\
(0.80 \text { to } 1.34)\end{array}$ & 1.35 & $\begin{array}{l}0.82 \\
(0.41 \text { to } 1.67)\end{array}$ & 1.01 & $\begin{array}{l}0.89 \\
(0.65 \text { to } 1.22)\end{array}$ \\
\hline Study population & 27450 & & 111370 & & 10400 & & 73129 & \\
\hline
\end{tabular}

(see tables 2 and 3). A further element that may have contributed to risk reduction was the general programme concerning road traffic injuries that was in place in the Montérégie Region during the bicycle helmet wearing campaign. This may have effected a number of environmental changes of importance, as revealed by the reduction of injuries (head and other than those to the head) among pedestrians (results not presented here).

The absolute gain in terms of a decrease in the number of hospitalisations attributable to bicycle related head injuries was higher among children from the average rich municipalities (diminishment in hospitalisation cases for bicycle related head injuries during the study period: average rich 52 and poor 23 for at total number of 111370 and, 27450 children exposed respectively). The relative gain, on the other hand, was just as great among children from poor and average rich municipalities. This is somewhat surprising when taking into account the lower penetration of the programme into the poor municipalities in terms of helmet wearing. ${ }^{14}$ It is possible that children from poor municipalities had more individual and environmental characteristics that increased their risk of head injury than those from average rich municipalities, and that helmet use became an important gain in terms of injury severity reduction (that is, hospitalisations). Alternatively, cycling may have been less common among children from the municipalities characterised as poor, and, in these, more common among comparatively well off children.

The fact that the programme's positive impact on head injury risk was maintained during the three year period following the completion of the programme may reflect the fact that duration of a programme is an important elementnot only for the acquisition and retention of safe behaviour, ${ }^{13}$ but also for obtaining favourable results in terms of reduced injury risk.

In summary, population based programmes of the kind developed in the Montérégie may have a favourable impact on the voluntary adoption of safety behaviours and injury risk levels, both within average rich and within less privileged areas. This, in turn, suggests that population based programmes have the potential to benefit children from less accessible groups, without stigmatising them unduly or threatening their autonomy. In this respect, the current trend that guides health planners towards the implementation of targeted (and more costly) programmes, applied selectively to children from underprivileged families, may be misguided..$^{30}$

To our knowledge, this study is the first to provide evidence of this kind. Impact assessments are few, and they do not pay attention to the difference that contextual deprivation can make. ${ }^{18-20}$ Otherwise, there is converging evidence that programmes on bicycle helmet wearing affect children's behaviour from deprived areas to a lesser extent. ${ }^{142}$ Our favourable results might have been attained for a variety of reasons-including identification of determinants of bicycle helmet wearing before the programme, the use of multiple complementary strategies involving different stakeholders (schools, retailers, parents, and other community groups), and a clear focus on antecedent and reinforcing factors in relation to target behaviours (ensuring the relevance and solidity of the programme).

In this evaluation, the availability of a comparison community, combined with assessment of the programme's penetration over time and the good quality of our injury data, strengthens the conclusions that can be drawn. Such conclusions, however, can only be drawn at area level, and we cannot claim that the programme was well adapted to particular children from any particular child or family related set of socioeconomic circumstances.

More importantly, the measure of socioeconomic status of the areas that we used, though strongly recommended, ${ }^{2633}$ cannot be regarded as providing a synthesis of the social and physical environmental contexts to which children from different living areas are exposed. As these kind of data were lacking, it would be valuable to combine the measure with other variables capturing such aspects in future studies.

A final limitation of the study lies in its lack of precise denominators for the pre-implementation and implementation periods of the programme. In general terms, changes in size of the populations of the target and comparison communities suggest that we may have underestimated the protective effect of the programme. In any case, as the observed reduction in the population in the Montérégie was comparatively small $(2 \%)$, the differences in risk levels found between periods and categories of municipalities are probably reliable. But we do not know if the population varied equally in the two categories of municipalities. 
In conclusion, the bicycle helmet wearing programme reduced head injuries significantly, with a similar relative gain in both categories of municipalities (poor and relatively rich). It appears that population based educational programmes of the kind developed in the Montérégie may have a favourable impact on targeted safety behaviours and injury risk levels within both average rich and less accessible areas. Possibly, such programmes have the potential to benefit children from less privileged groups without stigmatising them unduly. This may have strong implications for the future development and evaluation of education based injury prevention programmes.

\section{Authors' affiliations}

C Farley, Institut national de santé publique du Québec, Canada L Laflamme, M Vaez, Department of Public Health Sciences at Karolinska Institutet, Sweden

\section{REFERENCES}

1 Brown B, Farley C. The pertinence of promoting the use of bicycle helmet for 8 to 12 year old children. Chronic Dis Can 1989;10:92-6.

2 MacWilliam L, Mao Y, Nicholls E, et al. Fatal accidental childhood injuries in Canada. Can J Public Health 1987:78:129-35.

3 Cushman R, Down J, MacMillan N, et al. Bicycle-related injuries: a survey in pediatric emergency department. Can Med Assoc J 1990;143:108-12.

4 Schwartz HJ, Brison RJ. Bicycle-related injuries in children. A study in two Ontario emergency departments. Chronic Dis Can 1996;17:56-62.

5 Linn S, Smith D, Sheps S. Epidemiology of bicycle injury, head injury, and helmet use among children in British Columbia: a five year descriptive study. Inj Prev 1998;4:122-5.

6 Kraus JF, Five D, Conroy C. Incidence, severity, and outcomes of brain injuries involving bicycles. Am J Public Health 1987:77:76-8

7 Gallagher S, Finison K, Guyer B, et al. The incidence of injuries among 87,000 Massachusetts children and adolescents: results of the 1980-81 statewide childhood injury prevention program surveillance system. Am Public Health 1984;74:340-7.

8 Swedish Institute for Transport and Communications Analysis. Road traffic injuries 1998. Official Statistics of Sweden. Stockholm: Swedish Government Publishing Service, 1999.

9 Ekman R, Welander G, Svanstrom L, et al. Bicycle-related injuries among the elderly-a new epidemic? Public Health 2002;115:38-43.

10 Thompson SR, Rivara FP, Thompson DS. A case-control study of the effectiveness of bicycle safety helmets. N Engl J Med 1989;320:1361-6.

11 Thompson DC, Rivara FP, Thompson RS. Effectiveness of bicycle safety helmets in preventing head injuries. A case-control study. JAMA 1996;276:1968-73

12 Thompson DC, Nunn ME, Thompson RS, et al. Effectiveness of bicycle safety helmets in prevention of serious facial injury. JAMA 1996;276:1974-5
13 Farley C, Otis J, Benoit M. Evaluation of a four year bicycle helmet promotion campaign in Quebec aimed at children aged 8 to 12: impact on attitudes, norms and behaviours. Can J Public Health 1997;88:62-6.

14 Farley C, Haddad S, Brown B. The effects of a 4-year program promoting bicycle helmet use among children in Quebec. Am J Public Health 1996;86:46-51

15 DiGuiseppi CG, Rivara FP, Koepsell TD, et al. Bicycle helmet use by children. Evaluation of a community-wide helmet campaign. JAMA 1989;262:2256-61.

16 Parkin P, Spence L, Hu X, et al. Evaluation of promotional strategy to increase bicycle helmet use by children. Pediatrics 1993;91:772-7.

17 Rivara FP. Thompson DC, Patterson MQ, et al. Prevention of bicycle-related injuries: helmets, education and legislation. Ann Rev Public Health 1998;19:293-318.

18 Rivara FP, Thompson DC, Thompson RS, et al. The Seattle children's bicycle helmet campaign: changes in helmet use and head injury admissions. Pediatrics 1994;93:567-9.

19 Wood T, Milne P. Head injuries to pedal cyclists and the promotion of helmet use in Victoria, Australia. Accid Anal Prev 1988;20:177-85.

20 Schuffham PA, Langley DJ. Trends in cycle injury in New Zealand under voluntary helmet use. Accid Anal Prev 1997;29:1-9.

21 Otis J, Lesage D, Godin G, et al. Predicting and reinforcing children's intentions to wear protective helmets while bicycling. Public Health Rep1992;107:283-9.

22 Green LW, Kreuter M. Health promotion planning: an educational and environmental approach. 2nd edn. Mountain View: Mayfield Publishing, 1991.

23 Rogers EM. Diffusion of innovation. 3rd edn. New York: Free Press, 1983.

24 Campbell DT, Stanley JC. Experimental and quasi-experimental designs for research. Chicago: Rand McNally, 1966.

25 Statistics Canada. Census of population, 1996. Ottawa: Info-Centre sociosanitaire des régions de la Montérégie et des Laurentides, 2002.

26 Haan M, Kaplan GA, Camacho T. Poverty and health: prospective evidence from the Alameda County Study. Am J Epidemiol 1987; 125:989-98.

27 Statistics Canada. Low income cut-offs. Available at: http://www.statcan.ca/english/census2001/dict/fam021.htm

28 World Health Organisation. International classification of diseases. Geneva: WHO, 1977

29 Robinson DL. Head injuries and bicycle helmet laws. Accid Anal Prev 1996;28:463-75

30 Parkin PC, Hu X, Spence $L$, et al. Evaluation of a subsidy program to increase bicycle helmet use by children of low-income families. Pediatrics 1995; 96:283-7.

31 Royal ST, Kendrick D. A randomized controlled trial of an educational intervention to promote bicycle helmet use by school children in deprived areas. Proceedings of the 6th world conference on injury prevention and control, 2002 May.

32 Parkin PC, Spence L, Hu X, et al. Evaluation of promotional strategy to increase bicycle helmet use by children. Pediatrics 1993;91:772-7.

33 Cubbin C, Smith GS. Socioeconomic inequalities in injury: critical issues in design an analysis. Annu Rev Public Health 2002;23:349-75. 